\title{
Lysosomal Enzyme Activities and Low Density Lipoprotein Receptors in Circulating Mononuclear Cells
}

\author{
Effect of Insulin Therapy in Diabetic Patients
}

\author{
K. Henze and A. Chait \\ Division of Mctabolism and Endocrinology, Department of Medicine, University of Washington, Seattle, Washington, USA
}

\begin{abstract}
Summary. Methods for the measurement of the lysosomal enzymes acid cholesterol-ester hydrolase and $\mathrm{N}$-acetyl- $\beta$-glucosaminidase were adapted for use with freshly isolated circulating mononuclear cells. Activities of both these enzymes increased (to 259 and $147 \%$ of control values respectively) after 7 days of insulin therapy in diabetic subjects. Low density lipoprotein degradation by freshly isolated mononuclear cells increased simultaneously by $67 \%$ $(p<0.05)$. The findings in this pilot study suggest [1] that circulating mononuclear cells can be used to cvaluate the effect of metabolic changes in vivo on lysosomal enzymes and low density lipoprotein metabolism, and [2] that insulin can stimulate cellular lysosomal enzyme activity.
\end{abstract}

Key words: Insulin, diabetes, lysosomal enzymes, mononuclear cells, acid cholesterol ester hydrolase, $\mathrm{N}$-acetyl- $\beta$-glucosaminidase, low density lipoprotein.

Atherosclerotic cardiovascular disease frequently is associated with diabetes mellitus, coronary heart disease being the leading cause of death in diabetes today [1]. A prominent feature of the atherosclerotic lesion is lipid accumulation, predominantly as esterified cholesterol [2] in "foam cells". These cholesterol esters appear to be derived from plasma low density lipoproteins (LDL) $[3,4]$ that enter cells after binding to specific cell surface receptors. $\mathrm{LDL}$ is then internalized and undergoes lysosomal degradation [5]. De Duve has suggested that decreased lysosomal function plays a role in the pathogenesis of atherosclerosis and that cholesterol ester accumulation occurs because of a relative deficiency of acid cholesteryl-ester hydrolase activity in the lysosome [6].
The activities of aortic acid cholesterol ester hydrolase and other lysosomal enzymes have been shown to be significantly decreased in experimental diabetes [7]. Since altered lysosomal enzyme activities in experimental diabetes are corrected by insulin therapy [7], and since insulin enhances LDL receptor activity in vitro $[8,9]$, the present study was undertaken to determine whether insulin treatment of diabetic patients would increase lysosomal enzyme activity and degradation of LDL by freshly isolated mononuclear cells. Acid cholesterol esterase was measured because of its potential significance in cellular cholesterol ester accumulation. $\mathrm{N}$-acetyl- $\beta$ glucosaminidase, although not implicated in atherogenesis, was studied as a marker enzyme to determine if any changes observed were limited to cholesterol ester hydrolase or not. Mononuclear cells were used because they can be studied shortly after their removal from the patient and therefore should be representative of cells in vivo.

\section{Experimental Procedures}

\section{Materials}

Cholesterol $\left[1-{ }^{14} \mathrm{C}\right]$ oleate $(50-60 \mathrm{mCi} / \mathrm{mmol})$, sodium ${ }^{125}$ 1-iodide (carricr free in $0.1 \mathrm{~mol} / 1 \mathrm{NaOH}$ ) were obtained from Amersham $/$ Searle (Arlington Heights, Ill.). Aquasol and Triton X-100 were from New England Nuclear (Boston, Mass.). Sigma Chemical, (St. Louis, Mo.), supplied cholesterol oleate and bovine scrum albumin, and Supelco (Bellefonte, Pa.) supplied egg yolk lecithin and sodium taurocholate. 4-Methylumbelliferone was obtained from Eastman Kodak (Rochester, NY), and 4-methylumbelliferyl2 -acetamido-2-dcoxy- $\beta$-D-glucopyranoside from Koch Light I.aboratories (Colnbrook, Bucks, England). Erythrosin B was obtained from Fisher Scientific (Pittsburgh, Pa.) and Lymphoprep, a mixture of sodium metrizoate and Ficoll (final density, $1.077 \mathrm{~g}$ ? $\mathrm{ml}$ ), was obtained from Gallard-Schlesinger (Mincola, NY). Dulbecco's phosphate buffered saline, Hank's balanced salt solution and RPMI 1640 medium were purchased from GIBCO (Grand Island, NY). 
Table 1. Clinical data for the seven diabetic patients examined

\begin{tabular}{|c|c|c|c|c|c|c|c|c|}
\hline Patient & $\begin{array}{l}\text { Age } \\
\text { (years) }\end{array}$ & Sex & $\begin{array}{l}\text { Height } \\
\text { (m) }\end{array}$ & $\begin{array}{l}\text { Weight } \\
\text { (kg) }\end{array}$ & $\begin{array}{l}\text { Ideal } \\
\text { body } \\
\text { weight } \\
(\%)\end{array}$ & $\begin{array}{l}\text { Fasted plasma } \\
\text { glucose } \\
\text { (before insulin) } \\
\text { (mmol/) }\end{array}$ & $\begin{array}{l}\text { Fasted plasma } \\
\text { glucose } \\
\text { (after insulin) } \\
(\mathrm{mmol} / \mathrm{l})\end{array}$ & $\begin{array}{l}\text { Insulin dose } \\
\text { (U/day) }\end{array}$ \\
\hline 1 & 49 & Male & 1.79 & 80 & 114 & 24.1 & 9.4 & 30 \\
\hline 2 & 39 & Female & 1.74 & 107 & 171 & 10.8 & 13.2 & 10 \\
\hline 3 & 57 & Male & 1.81 & 79 & 110 & 20.9 & 14.3 & 20 \\
\hline 4 & 61 & Female & 1.56 & 80 & 158 & 18.5 & 10.2 & 25 \\
\hline 5 & 48 & Male & 1.74 & 81 & 121 & 14.9 & 7.2 & 20 \\
\hline 6 & 49 & Male & 1.74 & 70 & 105 & 14.7 & 10.0 & 35 \\
\hline 7 & 56 & Male & 1.72 & 93 & 139 & 18.5 & 14.7 & 50 \\
\hline
\end{tabular}

Percent ideal body weight was calculated from Metropolitan Life Insurance Tables for height and for the midpoint of the range for medium body frame

\section{Isolation of Mononuclear Cells}

Peripheral mononuclear cells were isolated from $60 \mathrm{ml}$ of blood obtained after an overnight fast by the method of Boyüm [10], as modified by Ho et al. [11]. The cells obtained were counted in a Coulter counter. Cell viability as assessed by erythrosin B exclusion, was always greater than $95 \%$. Differential counts revealed that $64-73 \%$ of the freshly isolated mononuclear cells were lymphocytes, the rest monocytes. Only occasional platelets could be seen on examination of the smears.

Preparation of Cell Free Extracts for Lysosomal Enzyme Determination. Cell pellets ( $2-3 \times 10^{6}$ cells) were dissolved in $1 \mathrm{ml}$ of $0.25 \mathrm{~mol} / 1$ sucrose, $1 \mathrm{mmol} / 1$ EDTA, containing $0.1 \%(\mathrm{v} / \mathrm{v})$ ethanol. Triton $X-100(0.1 \%, v / v)$ was mixed thoroughly with the cell pellet and incubated for $10 \mathrm{~min}$ at $37^{\circ} \mathrm{C}$ in a metabolic shaker. The cell extract so obtained was frozen at $-70^{\circ} \mathrm{C}$ until assayed within the next two weeks. The two enzymes measured were stable under these conditions for up to one month.

Assay of Acid Cholesteryt-ester Hydrolase (EC 3.1.1.13). Acid cholesterol ester hydrolase in mononuclear cell extracts was assayed essentially by the method described for use in other cell types [12]. To prepare $1 \mathrm{ml}$ of substrate, cholesterol- $\left[1-{ }^{14} \mathrm{C}\right.$ loleate [1 $\mu \mathrm{Ci}$ ], $10 \mathrm{nmol}$ of cholesterol oleate and $0.8 \mu \mathrm{mol}$ of egg yolk lecithin in benzene were mixed and dried under a stream of nitrogen. Na taurocholate $(0.25 \mathrm{ml}$ of $2.4 \mathrm{mmol} / \mathrm{l})$ was added and the mixture was sonicated on ice with a Branson Sonifier (Branson Instruments, Danburg, Conn.) for $20 \mathrm{~s}$ at setting 2.5 . Then $0.25 \mathrm{ml}$ of bovine serum albumin $(200 \mu \mathrm{g} / \mathrm{ml})$ and $0.2 \mathrm{~mol} / 1$ sodium acetate-acetic acid buffer, $\mathrm{pH} 4.0$ were added and thoroughly mixed. The reaction was started by adding $100 \mu \mathrm{l}$ of cell free extract to $100 \mu \mathrm{l}$ of substrate. Incubations were performed for $1 \mathrm{~h}$ at $37^{\circ} \mathrm{C}$.

The reaction was stopped by the addition of $3.25 \mathrm{ml}$ of ice-cold extraction mixture (chloroform-methanol-heptane, 1.25:1.41:1), $1 \mathrm{ml}$ of $0.5 \mathrm{~mol} / 1$ sodium carbonate-bicarbonate solution $\mathrm{pH} 10.5$ and $30 \mu \mathrm{l} 1 \mathrm{~mol} / 1 \mathrm{NaOH}$. After mixing thoroughly and centrifuging for $20 \mathrm{~min}$ at $800 \mathrm{~g}, 1 \mathrm{ml}$ of the upper phase was transferred to scintillation vials and counted in $10 \mathrm{ml}$ of Aquasol in a Packard Tricarb liquid scintillation spectrometer, model 3375 (Packard Instrument, Downers Grove, Ill.). A solution of radiolabelled oleic acid was used as internal standard. All assays were performed in duplicate.

Enzyme activity was linear with protein concentration up to $20 \mu \mathrm{g} / 100 \mu \mathrm{l}$, linear with time up to $180 \mathrm{~min}$, saturated with cholesterol oleate $200 \mu \mathrm{mol} / \mathrm{l}$ and had a $\mathrm{pH}$ optimum of 4 .
Assay of $N$-Acetyl- $\beta$-Glucosaminidase (EC 3.2.1.30). For the measurement of this enzyme, the fluorimetric method of Peters et al. [13] as modified by Fowler et al. [14] was adapted to use with mononuclear cells. Cell free extract $(0.1 \mathrm{ml})$ was incubated at $37^{\circ} \mathrm{C}$ for $60 \mathrm{~min}$ with $0.1 \mathrm{ml}$ of $0.2 \mathrm{~mol} / 1 \mathrm{4-methylumbelliferone-}$ 2 -acetamido-2-deoxy-B-D-glucopyranoside in $0.25 \mathrm{~mol} / 1$ sucrose containing $0.1 \mathrm{~mol} / \mathrm{l}$ acetate buffer $\mathrm{pH} 5.7$. The reaction was stopped by the addition of $2 \mathrm{ml} 50 \mathrm{mmol} / \mathrm{l} \mathrm{NaOH}$ glycine buffer $\mathrm{pH}$ 10.5 containing $5 \mathrm{mmol} / \mathrm{l}$ EDTA. The liberated 4-methylumbelliferone was measured in an Aminco SPF 500 fluorescence spectrometer with a xenon lamp power supply (Aminco, Silver Spring, Md.). The exciting wavelength was $365 \mathrm{~nm}$ and the emission wavelength was $460 \mathrm{~nm}$. Suitable enzyme and substrate blank assays were performed. Standard curves were obtained by mixing 4-methylumbelliferone in the appropriate buffer with $2 \mathrm{ml} \mathrm{NaOH}$ glycine buffer and measuring the amount of fluorescence as described above.

Enzyme activity was linear with protein concentration up to $6 \mu \mathrm{g} / 100 \mu \mathrm{l}$, with time up to $90 \mathrm{~min}$, saturated with substrate at $1.5 \mathrm{mmol} / \mathrm{l}$ and had a $\mathrm{pH}$ optimum of 5.7 .

Degradation of ${ }^{125}$ I-LDL by Intact Freshly Isolated Mononuclear Cells. LDL degradation by mononuclear cells was determined essentially by the method of Ho et al. [11] using LDL ( $d=$ 1.019-1.063) iodinated with ${ }^{125} \mathrm{I}$ by the iodine monochloride method as modified for lipoproteins [15] as previously described $[8,9]$. Four million freshly isolated cells in $1 \mathrm{ml}$ medium containing $30 \%$ lipoprotein deficient serum $(\mathrm{v} / \mathrm{v})$, were incubated with ${ }^{125} \mathrm{I}-$ $\mathrm{LDL}$ for $4 \mathrm{~h}$ at $37^{\circ} \mathrm{C}$ in the presence or absence of a 25 -fold excess unlabeled LDL. Degradation products of LDL were determined as previously described [9]. Nonspecific degradation was determined in dishes containing a 25 -fold excess of unlabeled LDL. Nonspecific degradation was subtracted from total degradation of ${ }^{125}$ I-LDL to give a measure of "high-affinity" LDL degradation [11].

Since freshly isolated mononuclear cells from normal subjects have low numbers of specific, high affinity LDL receptors, determination of cumulative LDL degradation over a period of time was used as an amplified measure of LDL binding to its receptor [11]. To evaluate the specificity of this assay, unlabelled lipoproteins were added in increasing concentration to determine their ability to compete with ${ }^{225}$ I-LDL for its degradation. Unlabelled LDL competed effectively with ${ }^{125}$ I-LDL for its degradation, while unlabelled high density lipoprotein ${ }_{3}\left(\mathrm{HDL}_{3}\right)$, which is virtually devoid of apoproteins recognised by the LDL receptor, did not 

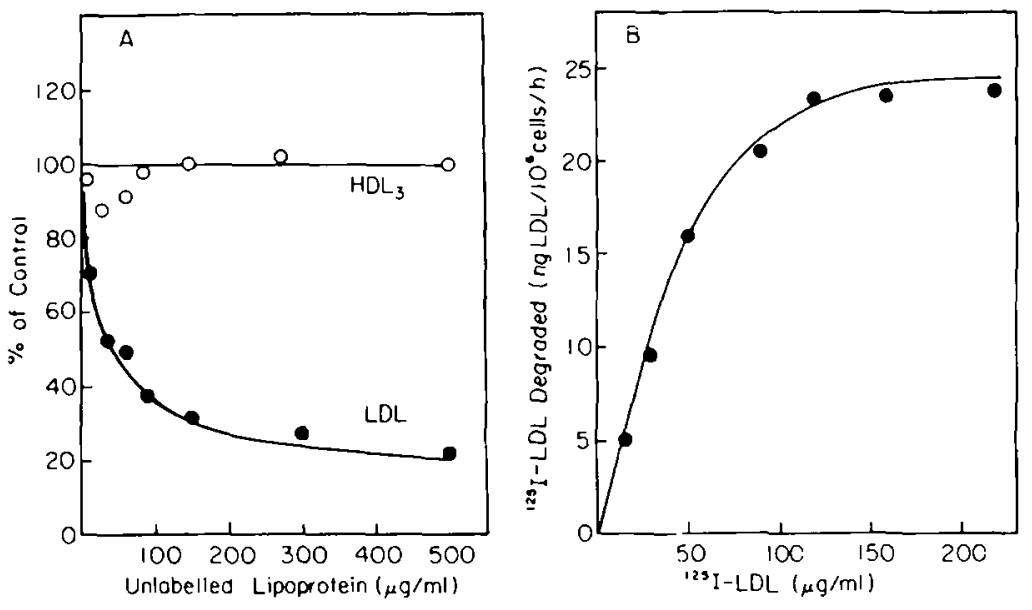

Fig. 1. Degradation of ${ }^{12.5}$ I-LDL by freshly isolated mononuclear cells. (A) To assess specificity, cells were incubatcd for $4 \mathrm{~h}$ with $7.5 \mathrm{\mu g} / \mathrm{ml}{ }^{125} \mathrm{I}$-labelled LDL and the indicated concentrations of cither unlabelled I.DL or high density lipoprotein ${ }_{3}\left(\mathrm{HDL}_{3}\right)$. ${ }^{175}$ I-LDL degradation was measured over the ensuing $4 \mathrm{~h}$. (B) To assess the saturability of high affinity degradation, freshly isolated mononuclear cells were incubated with the indicated amount of ${ }^{125}$ I-LDL for measurement of its degradation over the ensuing $4 \mathrm{~h}$. For each concentration of ${ }^{125}$ I-LDL a 25-fold excess of unlabelled LDL was added. The data points shown are total degradation minus that observed in the presence of excess unlabelled lipoprotein
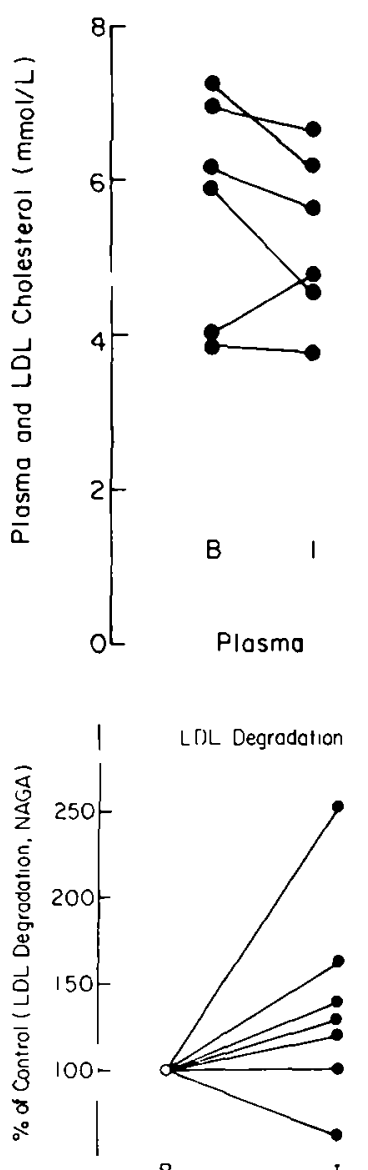

LDL Degradation
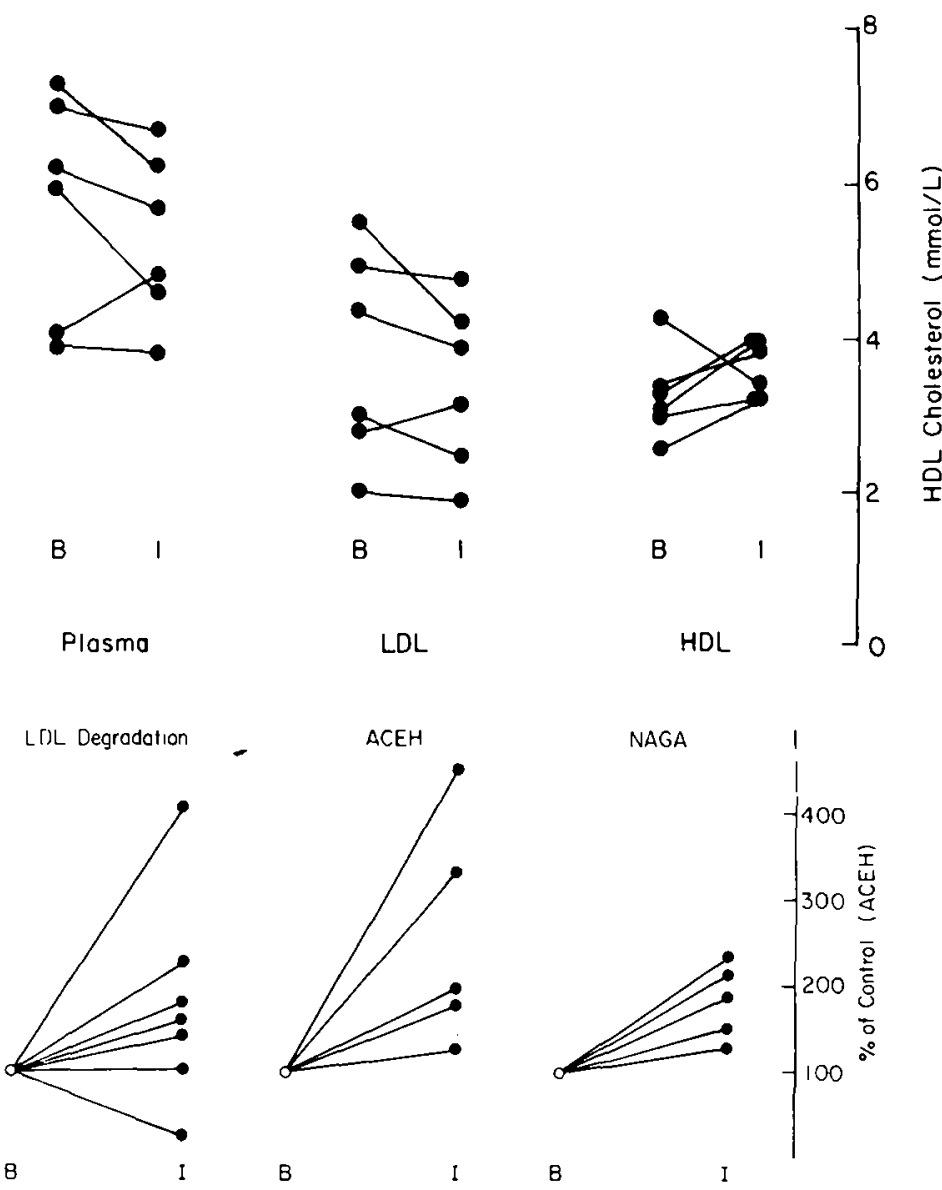

Fig. 2. Effect of 7 days of insulin therapy on plasma - low density lipoprotcin (LDL) and high density lipoprotein (HDL)-cholesterol in the diabetic patients. $\mathrm{B}=\mathrm{Basal}$; $\mathrm{I}=$ Insulin
(Figure 1A). When increasing concentration of ${ }^{125} \mathrm{I}-\mathrm{LDL}$ were added to cells, high affinity degradation was saturable (Figure 1B), suggesting that this assay provides a valid measure of $I$.DL receptor activity.

Patients and Protocol. Seven non-ketosis prone diabetics, aged 39-61 ycars (Table 1), were studied prior to their commencing insulin therapy and again after 1 week of treatment. Nonc was taking drugs other than insulin nor did any have associated dis- eases. Insulin was administered either as lente or isophane (NPH) insulin and was injected as a single dose in the morning. At the time of the repeat study, the mean insulin dose was $27 \pm 13 \mathrm{U} /$ day. Fasting plasma glucose fell from a pretreatment value of $17.5 \pm 4.4$ to $11.3 \pm 2.8 \mathrm{mmol} / \mathrm{l}$ at the time of the repeat study $(\mathrm{p}<0.02)$. Blood was drawn after a $12-14 \mathrm{~h}$ overnight fast $(24 \mathrm{~h}$ after the previous insulin dose) for the isolation of circulating mononuclear cells and for the determination of plasma glucose. cholesterol, triglyceride and lipoprotein levels.

Informed consent was obtained from all subjects. 
Other Assays. Cell protein content was determined by the Lowry method [16]. Plasma cholesterol and triglyceride were measured on an AAII autoanalyser using standard techniques [17]. Lipoproteins were quantified after preparative ultracentrifugation by standard methodology [17].

Statistics. Values before and after insulin treatment were compared by Student's paired t-test or Wilcoxon's paired sample test.

\section{Results}

Insulin therapy resulted in a decrease of fasting plasma glucose (Table 1), a decrease in total plasma triglyceride and cholesterol and low density lipoprotein cholesterol, while high density lipoprotein cholesterol was increased (Fig. 2). After 7 days of insulin therapy, degradation of ${ }^{125}$ I-LDL increased by $20-150 \%$ in 5 patients, did not change in one and fell slightly in the last (Fig. 3) $(\mathrm{p}<0.05)$. Lysosomal enzyme activities were determined in cell extracts from freshly isolated mononuclear cells in 5 patients. The activities of both acid cholesteryl ester hydrolase and $\mathrm{N}$-acetyl- $\beta$-glucosaminidase increased in the five patients studied (Fig. 3; $\mathrm{p}<0.05$ ).

\section{Discussion}

The findings in this study illustrate that freshly isolated circulating mononuclear cells can be used to evaluate changes in LDL metabolism in vivo. Cells isolated by density gradient centrifugation appear to metabolise LDL by the receptor-mediated LDL pathway in a manner analogous to other extrahepatic cells [5], despite circulating mononuclear cells being exposed to a higher concentration of LDL than is present in most tissues.

Insulin treatment in the diabetic patients led to the expected reduction in fasting plasma glucose and the capacity of the cells to degrade ${ }^{125} \mathrm{I}-\mathrm{LDL}$ increased. The findings agree with in vitro studies from our laboratory which indicate that insulin stimulates LDL degradation by increasing the number of LDL receptors on cultured human fibroblasts [9]. In the present study, plasma and LDL cholesterol levels fell concurrently. The degradation of ${ }^{125}$ I-LDL when added at a concentration on the high affinity part of its concentration curve, represents a time integrated measurement of LDL receptor activity $[9,11]$, since each cell surface LDL receptor will bind and hence internalise many LDL particles during the period of incubation. Although specific, high affinity saturable degradation by mononuclear cells resembles that seen in other cell types $[5,9,18]$, it is nonetheless conceivable that the increased LDL degradation observed during insulin therapy might reflect enhanced lysosomal breakdown of LDL. To address this question directly, it would be necessary to measure LDL degradation and binding concurrently. However, due to the high concentration of LDL in the bloodstream, LDL receptors are relatively suppressed in freshly isolated mononuclear cells, making accurate measurement of binding difficult with established methods. Thus, while our present pilot study suggests that the in vitro effect of insulin on the LDL pathway might also operate in vivo, we cannot yet conclude this positively.

The specific activities of several lysosomal enzymes, among them acid cholesteryl ester hydrolase, are decreased in experimental diabetes, in the face of increased circulating levels of cholesterol and lipoproteins [7]. De Duve has postulated that cholesterol ester accumulation in atherosclerotic vessels could reflect a relative deficiency of acid lipase within vascular smooth muscle cells [6]. In the presence of high levels of substrate (cholesterol-ester rich low density lipoproteins) incomplete hydrolysis of internalised LDL could lead to progressive intralysosomal accumulation of cholesteryl ester in arterial wall cells and hence to the development of arteriosclerotic vascular disease.

Decreased lysosomal hydrolase activities in experimental diabetes could be restored to normal values by insulin treatment [7]. Our preliminary data provide support that a stimulatory effect of insulin on lysosomal hydrolases also operates in man, although our data do not distinguish between an increase in lysosomal content and an increase in the specific activities of the enzymes. Further studies are needed to determine whether acid cholesterol activity is reduced in cells from diabetic patients, and what long-term effects such deficiencies might have on cellular cholesterol accumulation.

Acknowledgements. The authors would like to thank Marty Jensen and Tom Johnson for excellent technical assistance and Sharon Kemp for skilfully typing the manuscript. Dr. Henze was a recipient of a grant from the Deutsche Forschungsgemeinschaft (He 1088) and Dr. Chait is a recipient of a U. S. Public Health Service Special Emphasis Research Career Award in Diabetes/Cardiovascular Disease (1 K01 AM 00592). Supported in part by a grant from the Juvenile Diabetes Foundation (78R 159).

\section{References}

1. Bierman EL, Brunzell JD (1978) Interrelation of atherosclerosis, abnormal lipid metabolism and diabetes mellitus. In: Katzen H M, Mahler R J (eds) Diabetes, obesity and vascular disease. Halsted Press, Washington, p 187-210

2. Kritchevsky D, Kothari HV (1978) Arterial enzymes of cholesteryl ester metabolism. Adv Lipid Res 16: 221-266 
3. Smith E B, Slater RS (1972) Relationship between low density lipoprotein in aortic intima and serum-lipid levels. Lancet I: 463-469

4. Wolinsky H, Fowler S (1978) Participation of lysosomes in atherosclerosis. N Engl J Med 299: 1173-1178

5. Goldstein J L, Brown M S (1977) The low density lipoprotein receptor and its relationship to atherosclerosis. Ann Rev Biochem 46: 897-930

6. de Duve C (1974) The participation of lysosomes in the transformation of smooth muscle cells to foamy cells in the aorta of cholesterol-fed rabbits. Acta Cardiol (Brux) 20 [Suppl]: 9-25

7. Wolinsky H, Goldfischer S, Capron L, Capron F, ColtoffSchiller B, Kasak L (1978) Hydrolase activities in the rat aorta. I. Effects of diabetes mellitus and insulin treatment. Circ Res 42: 821-830

8. Chait A, Bierman E L, Albers J J (1978) Regulatory role of insulin in the degradation of low density lipoprotein by cultured fibroblasts. Biochim Biophys Acta 529: 292-299

9. Chait A, Bierman E L, Albers J J (1979) Low-density lipoprotein receptor activity in cultured skin fibroblasts: mechanism of insulin-induced stimulation. J Clin Invest 64: 1309-1319

10. Boyüm A (1968) Isolation of mononuclear cells and granulocytes from human blood. Isolation of mononuclear cells by one centrifugation, and of granulocytes by combining centrifugation and sedimentation at $1 \mathrm{~g}$. Scand J Clin Lab Invest 97 [Suppl 21]: 77-89

11. Ho Y K, Brown M S, Bilheimer DW, Goldstein J L (1976) Regulation of low density lipoprotein receptor activity in freshly isolated human lymphocytes. J Clin Invest 58: 1465-1474

12. Takano T, Black W J, Peters T J, de Duve C (1974) Assay, kinetics, and lysosomal localization of an acid cholesteryl esterase in rabbit aortic smooth muscle cells. J Biol Chem 249: 6732- 6737

13. Peters T J, Müller M, de Duve C (1972) Lysosomes of the arterial wall. I. Isolation and subcellular fractionation of cells from normal rabbit aorta. J Exp Med 136: 1117-1139

14. Fowler S, Shio H, Wolinsky H (1977) Subcellular fractionation and morphology of calf aortic smooth muscle cells. J Cell Biol 75: $166-184$

15. Langer T, Strober W, Levy R I (1972) The metabolism of low density lipoprotein in familial type II hyperlipoproteinemia. $J$ Clin Invest 51: 1528-1536

16. Lowry O H, Rosebrough N J, Farr A L, Randall R J (1951) Protein measurement with the Folin phenol reagent. J Biol Chem 193: 265-275

17. Lipid Research Clinic Manual of Laboratory Operations (1974) US Dept of Health, Education and Welfare, Washington, $\mathrm{DC}$

18. Chait A, Ross R, Albers J J, Bierman E L (1980) Plateletderived growth factor stimulates activity of low density lipoprotein receptors. Proc Nat Acad Sci USA 77: 4084-4088

Received: 23 June 1980

and in revised form: 13 October 1980

Alan Chait, M. D.

Department of Medicine

Division of Metabolism and Endocrinology (RG-20)

University of Washington

Seattle, WA 98195

USA 